\title{
Of contraception and morality
}

\author{
Lindsay Edouard
}

\section{Summary}

Perspectives on sexuality can be heavily influenced by considerations pertaining to morality, religion and science. With the emergence of a strong scientific basis for health care, sexual morality has moved away from ideology towards governance for the effective use of limited resources. The inclusion for the Millennium Development Goals, of both a target on universal access to reproductive health services and an indicator on contraceptive prevalence, should lead to more prominence for contraception in international development.

\section{Political perspective}

The National Association of Family Planning Doctors held a symposium entitled 'Some Moral Aspects of Family Planning' on 30 April 1982. Kenneth Clarke, the Minister of State for Health in the Conservative government of Margaret Thatcher, stated in his opening remarks ${ }^{1}$ that the association was a "unifying factor within the medical profession" by bringing medical practitioners together whether from family planning clinics, obstetrics and gynaecology, community, general or hospital practice thereby offering "a truly integrated service". 2 Besides, "contraception was accepted as a respectable part of general practice". 3

The Minister of State for Health reiterated that "this Government, like its recent predecessors, regards provision of family planning as one of the most important preventive services which should be available to everyone who needs it, irrespective of their marital status, sex, or age". Furthermore, he felt that the symposium addressed a "difficult theme" that "evokes the memory of the valiant struggles of early family planning stalwarts and opponents with religious and other objections to birth control" and acknowledged that the "detrimental social and economic effects of unwanted pregnancies, particularly in the young, make family planning a tremendous financial bargain". 1 Dr John Havard, Secretary of the British Medical Association, pointed out that the symposium should be seen in the context of the 50th anniversary of the 1932 report of the Departmental Committee on Maternal Mortality and Morbidity, that ensured the provision of contraceptive advice in maternal and child welfare clinics, as well as the earlier Lambeth Conference of 1930 that had given conditional approval to contraception. ${ }^{4}$ Therefore, British support for family planning as a central pillar for improving maternal and child health has a long trackrecord within both state and church.

\section{Adolescent services}

Feeling that "the greatest moral issue in the family planning field and the one that causes the greatest public excitement is the provision of contraceptive advice for children under 16", the Minister of State for Health stressed that parental involvement is desirable but contraception

\section{J Fam Plann Reprod Health Care 2007; 33(4): 283-284}

Larchmont, USA

Lindsay Edouard, FRCOG, FFFP, Member of the Editorial Advisory Board

Correspondence to: Professor Lindsay Edouard.

E-mail: soranae@gmail.com should not be withheld when persuasion of the patient fails. ${ }^{1}$ A request for contraception might imply "searching for individual identity" by adolescents. 5

With erroneous views regarding the relationship of emergency contraception to abortion, a "morality debate" was anticipated. There were issues such as "fear of encouraging irresponsibility" and staff attitudes including "inflexible appointment systems and 'dragon" receptionists". Despite meeting national advertising standards, small classified advertisements for emergency contraception were only accepted by a few national newspapers and it was recognised that "the question of 'offending the public taste' is still widely used as an argument against more direct advertisement". 6

\section{Cultural considerations}

The poor uptake of contraceptive services, despite media campaigns, led to the consideration of relationships in the sociocultural context of moral values. ${ }^{7}$ Behaviour change communications should take into account attitudes towards sex: anxiety is generally hidden under intellectualism by the middle class whereas sex seemed to be more acceptable by the working class for the purpose of procreation. ${ }^{8}$

In certain societies, a didactic approach is expected from the medical practitioner with for clinical interventions even in the absence of an evidence-based rationale. ${ }^{9}$ Provider bias plays an important role in differences between countries for the utilisation of contraceptive methods. With "the mysteries and magic of medicine becoming even more inscrutable", concern was expressed for disregard of the viewpoints of clients as "doctors often don't realise quite how great their influence can be". ${ }^{10}$

When "veiled women come to have IUDs fitted, often secretly as their husbands don't approve", service providers should appreciate "the importance of suiting the method of birth control to the needs and culture of the individual". ${ }^{11}$ In developing countries, the importance of family planning was already well accepted for its role in poverty reduction, being recognised by a medically qualified Catholic nun who provided injectable contraceptives and tubal ligations as she felt that "it was the only way to help her poor flock out of its poverty". ${ }^{12}$ The provision of effective modern methods of contraception is necessary to prevent unsafe illegal abortions following unwanted pregnancies from ineffective contraceptive methods such as Oheba, consisting of mental exercises that supposedly close the cervix thereby preventing sperms from going through. ${ }^{12}$

\section{Implications for sexual health}

With unintended pregnancies, "both abortion and adoption involve irrevocable and often painful decisions with a strong moral component" and counselling is invaluable "as a welcome counterbalance to the unsought advice, moralising and clumsy intrusion into their personal affairs". ${ }^{13}$ When problems arise in practice, "a genuine respect for the moral autonomy of the other parties involved must above all be safeguarded" and "neither the patient nor the profession should put any pressure on a doctor to act contrary to his conscientious moral position". 14

With the emergence of liberalism, religiosity has become largely a private matter that does not impinge on most aspects of society and the lives of individuals. The 
concept of morality has moved largely towards ethics, integrity, accountability and transparency in governance as opposed to socio-religious overtones that persist in some aspects of sexual health. As medical ethics focus on the protection of patients, the moral beliefs of service providers should not hamper service provision on religious or other grounds of conscience, and in such cases referral is necessary. ${ }^{4}$

There is a long tradition for an influence of theology on the legal status of contraception. Whereas the surgical removal of the uterus and gonads has been theologically acceptable for indications of malignancy, sterilisation was denounced as not only immoral but probably illegal in Britain as late as the $1950 \mathrm{~s} .{ }^{15}$ It is most opportune to note the well-entrenched practice, from the late 16th until the late 19th century in Rome, of castration of prepubertal boys aged around 8 years for the preservation of the unbroken male voice of those castrati. Castration eliminates the effect of testicular secretions that increase the length and mass of the vocal cords: the lower pitch of the male voice from puberty is thereby avoided. As a result, the castrato had unique features for performing the intricate church music of the choir of the Sistine Chapel and later on, from the early 17 th century, for the Italian opera. ${ }^{16}$

With sexual pleasure without the risk of pregnancy being sometimes considered as sinful, ${ }^{4}$ contraception has been incriminated for the drastic change in the role of sexual intercourse for procreation, recreation becoming the sole aim of coitus. ${ }^{17,18}$ Differences in the progressive liberal and traditional authoritarian approaches pivot on the relative importance of evidence for improving health outcomes as opposed to ideology and politics. ${ }^{19-21}$ With contraception having been associated with lewd and lascivious literature besides indecent exposure and bawdy houses, the law courts had much earlier held that contraception constituted a criminal offence but condoms could be provided for preventing venereal disease. ${ }^{4}$ The recent inclusion of a target on universal access to reproductive health as part of the maternal health goal for the Millennium Development Goals, besides the measurement of contraceptive prevalence rate as an indicator, underscores the importance of contraceptive services. Much more remains to be done in the quest for an improved quantitative approach for policy formulation to allay the fear that advocacy is outpacing science. $^{22}$

Having lived through the sexual revolution, parents should be well aware of the current issues surrounding adolescent sexual and reproductive health. Unfortunately, sexuality education continues to be shrouded in controversy even with the threat of HIV. Whereas a clinical diagnosis of squamous cervical carcinoma does not raise issues regarding the past sexual history of the patient, the recent introduction of human papillomavirus vaccination for primary prevention immediately led to opposition concerned about promiscuity. It is apt to be reminded of the situation in 1982 in Britain when the Conservative government singled out the special value, of emergency contraception for adolescents, a position in sharp contrast to the unfortunate controversy that persists in some countries despite the objective supporting evidence of the intervening years.

\section{Statements on funding and competing interests \\ Funding None identified.}

Competing interests None identified.

\section{References}

1 Clarke K. Opening remarks. Br J Fam Plann 1982; 8(Suppl): $1-2$.

2 Editorial. Affiliated groups - a vital role. Br J Fam Plann 1982; 8: 77.

3 Evans B. An integrated service. Br J Fam Plann 1982; 7: 122-123.

4 Havard J. Legal and ethical considerations for doctors in family planning. Br J Fam Plann 1982; 8(Suppl): 16-19.

5 Editorial. What is the doctors' duty? Br J Fam Plann 1982; 8: 1.

6 Skrine R. Postcoital birth control. Br J Fam Plann 1982; 8: 66-69.

7 Bostock Y, Leathar DS. The role of mass media advertising campaigns in influencing attitudes towards contraception among 16-20 year olds. Br J Fam Plann 1982; 8: 59-63.

8 Kirkman RJE. The art and science of family planning. Br J Fam Plann 1982; 7: 125-127.

9 Christopher E. Psychosexual medicine in a mixed racial community. Br J Fam Plann 1982; 7: 115-119.

10 Toynbee P. Sterilisation - the danger of over-promotion. $\mathrm{Br} \mathrm{J}$ Fam Plann 1982; 8(Suppl): 13-15.

11 Cardy G. Passage to India. Br J Fam Plann 1982; 8: 109-110.

12 Cardy G. A republic of 13,000 islands. Br J Fam Plann 1982; 8: 63-64.

13 Cheetham J. Alternatives to termination - making the decision. Br J Fam Plann 1982; 8: 101-104.

14 Hughes G. Family planning - some Catholic comments. $\mathrm{Br} \mathrm{J}$ Fam Plann 1982; 8(Suppl): 19-22.

15 Kennedy I. The regulation of reproduction: rights and responsibilities. Br J Fam Plann 1982; 8(Suppl): 2-8.

16 Jenkins JS. The lost voice: a history of the castrato. $J$ Pediatr Endocrinol Metab 2000; 13(Suppl 6): 1503-1508.

17 Dominian J. Moral and psychological aspects of coitus and contraception. Br J Fam Plann 1982; 8(Suppl): 11-13.

18 Djerassi C. Are sex and fertilisation ready for divorce? Lancet 2006; 368(Suppl): S55-S57.

19 Sanger A. Beyond Choice: Reproductive Freedom in the 21st Century. New York, NY: PublicAffairs, 2004; 261-267.

20 Fleming T. The Morality of Everyday Life: Rediscovering an Ancient Alternative to the Liberal Tradition. Columbia, MO: University of Missouri Press, 2004; 164, 192, 229.

21 Carter J. Our Endangered Values: America's Moral Crisis. New York, NY: Simon \& Schuster, 2005; 57-58, 71.

22 World Health Organization and United Nations Children's Fund. Measurement in the Real World of Programmes. Document $\mathrm{FCH} / \mathrm{CAH} / 01.03$. Geneva, Switzerland: World Health Organization, 2001; 7-14, 24-33. 